Original Article

\title{
Biology of Glyphepomis dubia Campos \& Souza, 2016 (Hemiptera: Pentatomidae) and the parasitoids Telenomus podisi Ashmead, 1893 and Trissolcus basalis (Wollaston, 1858) (Hymenoptera: Platygastridae) on rice
}

\author{
Biologia de Glyphepomis dubia Campos \& Souza, 2016 (Hemiptera: Pentatomidae) e \\ dos parasitoides Telenomus podisi Ashmead, 1893 e Trissolcus basalis (Wollaston, 1858 \\ (Hymenoptera: Platygastridae) em arroz
}

\begin{abstract}
J. R. Souza ${ }^{a^{*}}$ (D) C. G. Silva ${ }^{b}$ (D) J. A. F. Barrigossic (D), J. B. Matos Junior ${ }^{b}$ (D), D. P. Conceição ${ }^{d}$ (D) and G. O. Sousa ${ }^{b}$ (D) aUniversidade Estadual do Maranhão - UEMA, Departamento de Fitotecnia e Fitossanidade, Centro de Ciências Agrárias, São Luís, MA, Brasil bUniversidade Federal do Maranhão - UFMA, Departamento de Biologia, Centro de Ciências Agrárias e Ambientais, Chapadinha, MA, Brasil 'Empresa Brasileira de Pesquisa Agropecuária - EMBRAPA, Laboratório de Entomologia, Embrapa Arroz e Feijão, Santo Antônio de Goiás, GO, Brasil

dUniversidade Federal do Maranhão - UFMA, Programa de Pós-graduação em Biodiversidade e Conservação, São Luís, MA, Brasil
\end{abstract}

\begin{abstract}
The life cycle of stink bug, Glyphepomis dubia and the development of two egg parasitoids (Telenomus podisi and Trissolcus basalis) were studied at the Federal University of Maranhão, at $26 \pm 2{ }^{\circ} \mathrm{C}$, relative humidity (RH) of $60 \pm 10 \%$ and $12 \mathrm{~h}$ photophase. Individuals used in the study were collected from seven rice fields located around the municipality of Arari, Maranhão, Brazil, and maintained in greenhouse and laboratory for the life cycle studies. From egg to adult, G. dubia took 35.2 days to complete the life cycle. The oviposition period was 37 days, with egg masses of about 12 eggs each and viability of 93.1\%. Longevity was 53 and 65 days for females and males, respectively. The egg parasitoids Te. podisi and Tr. basalis parasitized and developed in G. dubia eggs; however, the biological characteristics of Tr. basalis were affected. Emergence of the parasitoids was higher for Te. podisi (83.5\%) compared to the records for Tr. basalis (50.4\%). Therefore, G. dubia may potentially achieve a pest status and Te. podisi is a promising biological control agent for G. dubia management in Brazil due to its higher longevity and better reproductive parameters.
\end{abstract}

Keywords: Heteroptera, Oryza sativa, egg parasitoids, rice stink bugs, control biology.

\begin{abstract}
Resumo
O ciclo de vida do percevejo, Glyphepomis dubia e a biologia de dois parasitoides de ovos (Telenomus podisi e Trissolcus basalis) foram estudados na Universidade Federal do Maranhão, a $26 \pm 2^{\circ} \mathrm{C}$, umidade relativa (UR) de 60 $\pm 10 \%$ e fotofase de $12 \mathrm{~h}$. Sete indivíduos de G. dubia foram coletados em lavoura de arroz localizada no município de Arari, Maranhão, Brasil e mantidos em casa de vegetação e laboratório para estudos de ciclo de vida. Do ovo ao adulto, G. dubia levou 35.2 dias para completar o ciclo de vida. O período de oviposição foi de 37 dias com massas de ovos com cerca de 12 ovos/massa e viabilidade de $93.1 \%$. A longevidade foi de 53 e 65 dias, respectivamente, para fêmeas e machos. Os parasitoides de ovos, Te. podisi e Tr. basalis parasitaram e se desenvolveram em ovos de G. dubia, no entanto as características biológicas de Tr. basalis foi afetada. A emergência dos parasitoides foi maior para Te. podisi (83.5\%) em comparação com o registrado para Tr. basalis (50.4\%). Portanto, G. dubia poderá apresentar potencial para atingir o status de praga e Te. podisi é um promissor agente de controle biológico para ser utilizado no manejo de G. dubia no Brasil, pois apresentou maior longevidade e os melhores parâmetros reprodutivos.
\end{abstract}

Palavras-chave: Heteroptera, Oryza sativa, parasitoides de ovos, percevejos do arroz, controle biológico.

\section{Introduction}

The State of Maranhão is the eighth largest rice producer in Brazil and the second in the Northeast region, with estimates for $2020 / 2021$ harvest pointing to a total cultivated area of 8.4 thousand hectares, production of 5.690 thousand tons and average productivity of $2.753 \mathrm{~kg} / \mathrm{ha}$ (CONAB, 2021). In spite of the privileged position of the

*e-mail: joseaneagro@yahoo.com.br

Received: Jan. 11, 2021 - Accepted: May 20, 2021 
State with regard to rice production in the Northeast region, this cereal faces phytosanitary problems that may damage crop productivity.

The incidence of pests such as the species of Pentatomidae in agricultural crops emerges as a limiting factor, since they interfere with productivity and grain quality, resulting in economic losses. Pentatomidae is one of the most abundant families of stink bugs attacking rice crops in Brazil (Acosta et al., 2017). The rice stem bug Tibraca limbativentris Stål and the small rice stink bug Oebalus poecilus (Dallas) (Heteroptera: Pentatomidae) have been reported as the most economically important phytophagous stink bugs found in rice crops (Ferreira et al., 1997; Ferreira, 1998, 2006).

Glyphepomis dubia Campos \& Souza was described by Bianchi et al. (2016) from specimens collected in the municipality of Arari, Maranhão (03ํำ'13"S and $\left.44^{\circ} 46^{\prime} 48^{\prime \prime} \mathrm{W}\right)$. The authors presented a detailed morphological description of the species, relating it to other stink bugs belonging to the same genus occurring in different Brazilian regions. However, the article only provides its taxonomic description and distribution based on the location where specimens were collected there is no information besides those present in the original description.

Glyphepomis spinosa and Glyphepomis adroguensis Berg have been reported as potentially harmful to rice crops compared to other relevant species belonging to the Pentatomidae complex of rice pests in Brazil (Alves et al., 2012; Farias et al., 2012). Although Glyphepomis is a widely distributed genus in the Neotropical Region, only a few studies have been conducted to evaluate it, including biological studies on G. spinosa in rice (Alves et al., 2012), a description of immature individuals (Pollo et al., 2012) and a record of $G$. adroguensis as an egg parasitoid (Farias et al., 2012). Glyphepomis dubia biology and ecology remain unknown, and further studies are needed as a basis to reinforce the integrated pest management in rice.

The management of rice stink bugs in Brazil is based on the use of chemical insecticides (Martins et al., 2009; Pazini et al., 2015), without considering the principles of integrated pest management (Martins et al., 2009). The conservation of beneficial insects in rice stands out as an important component in modern integrated pest management (IPM) (Rahaman and Stout, 2019). For biological control, there are several studies involving surveys of natural enemies (e.g. Idalgo et al., 2013; Maciel et al., 2007; Riffel et al., 2010; Zachrisson et al., 2014a; Zachrisson et al., 2018) and application the Metarhizium anisopliae (Metchnikoff) Sorokin (Fungi: Hypocreales: Clavicipitaceae) in rice (Martins et al., 2004).

Regarding to parasitoids, eggs of different species of stink bugs the rice are parasitized by Telenomus podisi Ashmead and Trissolcus basalis (Wollaston) (Hymenoptera: Platygastridae). In Brazil, the specie Te. podisi was reported including T. limbativentris (Idalgo et al., 2013; Maciel et al., 2007; Riffel et al., 2010), O. poecilus (Dallas) (Melo Neto et al., 2020) and G. adroguensis (Farias et al., 2012). In Panama, in addition to Te. podisi em ovos de Euchistus nicaraguensis Rolston (Zachrisson et al., 2018), Tr. basalis has been reported parasitizing eggs of $T$. limbativentris (Zachrisson et al., 2014a) and Oebalus insularis Stål (Zachrisson et al., 2014b).

The trophic interaction between the host (as a potential pest) and the egg parasitoid species may provide relevant information for rice IPM in Brazil. The present study aims to assess the biology of G. dubia and the parasitoids Te. podisi and Tr. basalis on rice.

\section{Materials and Methods}

\subsection{Host rearing}

Seven adults of G. dubia were collected (four females and three males) in rice in the municipality of Arari, Maranhão, Brazil (03ํ 27 '13” S, 44 46 “48” W) in April and May 2012. The identification of the species G. dubia, was made by Dr. Luiz Alexandre de Campos, from the Department of Zoology, of the Universidade Federal de Rio Grande do Sul, Porto Alegre, Brazil that used the work of Bianchi et al. (2016).

Studies were performed in a greenhouse and laboratory at the Federal University of Maranhão, Chapadinha campus, Brazil. In the greenhouse, rice plants Oryza sativa L. (BR IRGA 409) grown in eight-liter plastic pots were used for stink bug feeding and reproduction. Plants were replaced every 20 days. The pots were inspected daily, egg masses collected daily from the plants to avoid egg parasitization (Alves et al., 2012) every two or three days and incubated in transparent plastic boxes ( $11 \mathrm{x} 11 \mathrm{x}$ $3.5 \mathrm{~cm}$, Adria Laboratórios, Londrina, Paraná, Brazil) lined with water-moistened filter paper $\left(26 \pm 2^{\circ} \mathrm{C}, 60 \pm 10 \% \mathrm{RH}\right.$, $12 \mathrm{~h}$ photophase) until second instar.

When the nymphs reached the second instar, they were confined to rice plants grown in pots in a greenhouse covered with cage made with "voile" ( $0.60 \times 1.45 \times 0.60 \mathrm{~m})$. The nymphs were followed daily until the adulthood.

\subsection{Biology of Glyphepomis dubia}

Thirty egg masses with approximately 16 eggs each, totalizing 480 eggs were taken to the laboratory, placed into Petri dishes $(9 \times 1.5 \mathrm{~cm})$, and kept under the same conditions described before. For each egg mass, the number of eggs and the oviposition date were recorded to determine the incubation period (in days), the viability of the eggs and the duration of the first instar (in days).

Upon reaching the second instar, nymphs were transferred to 45-day-old rice plants in a greenhouse and were reared until the end of the study. The development of each individual nymph was followed throughout the instars until reaching the adult stage by daily inspections, with counting and registration of the alive, dead and any missing individual. The time of development of each stage was determined, and survival ratio was calculated as the difference between the number of individuals alive in two consecutive stages.

The sex ratio was determined by dividing the number of emerged females by the total number of emerged adults. Survivorship and longevity the adult were determined using twenty five, couples individually kept in rice plants in a greenhouse. Each couple was observed daily to verify the 
egg masses, the presence of alive or dead individuals, and determine the periods of pre-oviposition and oviposition (in days).

Based on these daily observations, the egg masses of each couple were transferred to Petri dishes, kept in the laboratory the incubation period and viability (\%) were determined. In addition, the number of egg masses/female/ day, eggs/egg masses, incubation period, viability eggs (\%) and longevity of females and males was also observed.

\subsection{Biology of Telenomus podisi and Trissolcus bassalis on Glyphepomis dubia eggs}

Thirty G. dubia egg masses containing about 16 eggs ( $<24 \mathrm{~h}$ old) were individually glued to a white carton ( $3 \mathrm{x}$ $6 \mathrm{~cm}$ ) with paper glue (Tenaz, Henkel). Then, each carton containing a glued egg mass was introduced in a $5 \mathrm{~mL}$ test tube (model K30-1275PP transparent, 12 x 75 mm, Kasvi, Olen, São José dos Pinhais, Paraná, Brazil) covered with plastic film and held horizontally. In each tube containing one egg mass, a couple of virgin Te. podisi or Tr. basalis (one male and one female, both acquired from Embrapa Soja, Londrina, Paraná, Brazil) was introduced. These species of parasitoids were chosen because both perform well parasitizing eggs of most of pentatomids and they are easily reared in laboratory.

The parasitoids were allowed to stay in contact with the egg mass for 24 hours, and then were removed. Cards with eggs were transferred to similar tubes and kept in a climate room at $26 \pm 2^{\circ} \mathrm{C}$, relative humidity of $60 \pm 10 \%$ and photophase of 14 hours until the emergence of the parasitoids. Parasitism was evaluated individually for each species. The following biological variables were determined: parasitism (\%), emergence (\%), non-emerged parasitized eggs (\%), egg-to-adult period (in days), sex ratio and longevity of females and males without food (in days).

Parasitism was species determined by observing the eggs to detect any dark color and later by checking the emergence of adult parasitoids or stink bug nymphs (Pastori et al., 2010). All non-emerged eggs were dissected under the microscope to confirm the parasitism (Pacheco and Corrêa-Ferreira, 2000).

The egg-to-adult period (in days) was determined by computing the number of days starting from the day the wasps' eggs were laid to the emergence of the parasitoids. All emerged parasitoids were sexed according to the morphological characteristics of the antennae and the sex ratio (number of females/number of females + number of males) was calculated according to the equation reported by Pastori et al. (2010). Longevity of parasitoids was determined by following them since their emergence until the death (Doetzer and Foerster, 2007).

The differences in parasitism (\%), emergency (\%), non-emerged parasitized eggs (\%), egg-to-adult period (in days), sex ratio, and longevity of females and males (in days) were obtained through analysis using the MannWhitney Test (U test) at $5 \%$ significance level. This test was chosen because Shapiro-Wilk test showed a non-normal distribution of the data.

The analyses was performed using PAST 4.05 statistical program, January 2021 version (Hammer et al., 2001).

\section{Results}

\subsection{Biology of Glyphepomis dubia}

Eggs of G. dubia are initially light green becoming reddish and/or dark brown in a more advanced stage. Females lay their eggs on the upper face of the rice leaves and on the stalks of rice plants as well.

To complete one generation in rice, G. dubia requires 49.9 days. The egg incubation period for $G$. dubia was $5.9 \pm 0.05$ days and egg viability was $91.5 \pm 2.1 \%$ (Table 1 ). Glyphepomis dubia nymphs and adults feed by inserting their mouth parts into the stalk of the rice plant in a characteristic "upside down" position (Figure 1).

The fourth and fifth instars were the longest, lasting $6.3 \pm 0.22$ and $10.4 \pm 0.10$ days, respectively, while the first instar was the shortest with $3.1 \pm 0.04$ days; the nymphal period lasted $29.3 \pm 0.32$ days and the survivorship of the

Table 1. Instar-specific duration (mean $\pm \mathrm{SE}$ ) for Glyphepomis dubia kept under laboratory conditions $\left(26 \pm 2^{\circ} \mathrm{C}\right.$; relative humidity of $60 \pm 10 \%$ and $12 \mathrm{~h}$ photophase). Chapadinha, State of Maranhão, Brazil, 2012.

\begin{tabular}{|c|c|c|c|}
\hline Stage & Stadium & Duration (days) & Range (days) \\
\hline \multirow[t]{2}{*}{$\operatorname{Egg}^{1}$} & Incubation time & $5.9 \pm 0.05$ & $5-6$ \\
\hline & Egg viability (\%) & $91.5 \pm 2.10$ & $58-100$ \\
\hline \multirow[t]{8}{*}{ Nymph } & First instar & $3.1 \pm 0.04$ & $3-4$ \\
\hline & Second instar & $4.7 \pm 0.15$ & $5-7$ \\
\hline & Third instar & $4.8 \pm 0.22$ & $5-6$ \\
\hline & Fourth instar & $6.3 \pm 0.22$ & $6-9$ \\
\hline & Fifth instar & $10.4 \pm 0.10$ & $10-11$ \\
\hline & Nymphal time & $29.3 \pm 0.32$ & $28-32$ \\
\hline & Nymph survivorship (\%) & $39.0 \pm 5.00$ & $9-16$ \\
\hline & Egg-adult & $35.2 \pm 0.35$ & $27-36$ \\
\hline
\end{tabular}

${ }^{1}$ Results based on 30 egg masses with mean of 16 eggs. 
nymphs was $39 \pm 5 \%$ (Table 1 ). G. dubia took $35.2 \pm 0.35$ days from egg deposition to adult (Table 1), with 151 adults from which 96 males and 55 females, resulting in a sex ratio of $0.4 \pm 0.05$ (Table 2 ).

Glyphepomis dubia lays eggs in groups arranged in double rows. The female started the oviposition at $5 \pm$ 0.4 days of adult stage and remained laying eggs for $37 \pm$ 2.5 days (Table 2 ). Each female showed average number of

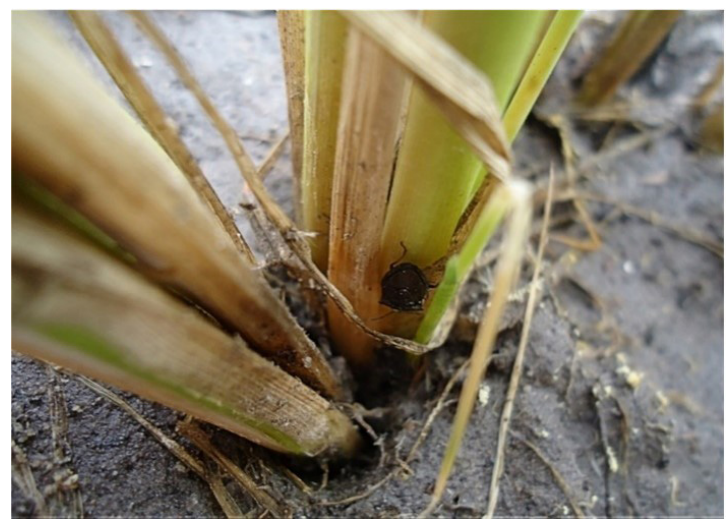

Figure 1. Adult the Glyphepomis dubia feeding on stems of rice in characteristic "upside down" position. Chapadinha, MA. 2012. eggs per egg lay was $12 \pm 1$, with a range from 7 to 13 eggs/ egg masses (Table 2). Regarding egg viability, $93 \pm 3 \%$ of the eggs were viable (Table 2). Adult females lived $53 \pm$ 4.5 days, ranging from 21 to 74 days, while males lived $65 \pm 2.9$ days, ranging from 49 to 82 days (Table 2 ).

\subsection{Biology of Telenomus podisi and Trissolcus basalis in Glyphepomis dubia eggs}

Telenomus podisi and Tr. basalis parasitized and developed in G. dubia eggs (Table 3). The was significant differences for emergence (\%), non-emerged parasitic eggs (\%), egg-to-adult period (in days), sex ratio, longevity of females and males (in days) (Table 3 ). The parasitoid emergence was higher for Te. podisi $(83.5 \pm 6.2 \%)$, compared to those registered for Tr. basalis ( $50.4 \pm 5.0 \%$ ) and the rate of non-emerged parasitized eggs was $3.8 \pm 1.4 \%$ for Te. podisi and $48 \pm 5.0 \%$ for Tr. basalis (Table 3 ).

From egg to adult, $T$ e. podisi required $11.74 \pm 0.08$ days to develop in G. dubia eggs, while Tr. basalis required $9.9 \pm$ 0.38 days under the same conditions. The sex ratios of Te. podisi and $T r$. basalis progenies were $0.6 \pm 0.01$ and $0.7 \pm$ 0.05 , respectively (Table 3 ). The longevities of Te. podisi and Tr. basalis were $2.74 \pm 0.08$ and $1.5 \pm 0.1$ days for females, while for males the longevity rates were $2.6 \pm 0.06$ and $1.9 \pm 0.19$ days, respectively (Table 3 ).

Table 2. Biological variables (mean \pm SE) for adults of Glyphepomis dubia kept under laboratory $\left(26 \pm 2^{\circ} \mathrm{C}\right.$, relative humidity of $60 \pm 10 \%$ and $12 \mathrm{~h}$ photophase) and greenhouse $\left(25 \pm 7^{\circ} \mathrm{C}\right.$, relative humidity of $60 \pm 20 \%$ and 14:10 L:D photoperiod) conditions. Chapadinha, State of Maranhão, Brazil, 2012.

\begin{tabular}{lrc}
\hline \multicolumn{1}{c}{ Variables } & Mean \pm SE & Range \\
\hline Sex ratio $^{1}$ & $0.4 \pm 0.05$ & $0.25-0.78$ \\
Pre-oviposition period $^{2}$ & $5 \pm 0.40$ & $1-8$ \\
Oviposition period $^{2}$ & $37 \pm 2.50$ & $20-60$ \\
Eggs/egg masses $^{2}$ & $12 \pm 1.00$ & $7-13$ \\
Egg viability (\%) $^{2}$ & $93 \pm 3.00$ & $68-100$ \\
Female longevity (days) $^{3}$ & $53 \pm 4.50$ & $21-74$ \\
Male longevity (days) $^{3}$ & $65 \pm 2.90$ & $49-82$ \\
\hline
\end{tabular}

${ }^{1}$ Results based on 191 individuals (96 males and 55 females); ${ }^{2}$ Results based on 480 eggs; ${ }^{3}$ Results based on 25 couples.

Table 3. Biological variables obtained by the Test Mann-Whitney (mean \pm SE) for Telenomus podisi and Trissolcus basalis developed in Glyphepomis dubia eggs in laboratory $\left(26 \pm 2^{\circ} \mathrm{C}\right.$, relative humidity of $60 \pm 10 \%$ and 14 h photophase). Chapadinha, State of Maranhão, Brazil, 2012.

\begin{tabular}{|c|c|c|c|c|}
\hline \multirow{2}{*}{ Biological variables $^{1}$} & \multicolumn{2}{|c|}{ Mean $\pm S E$} & \multirow{2}{*}{ Mann-Whitney } & \multirow{2}{*}{ Valor de p } \\
\hline & Telenomus podisi & Trissolcus basalis & & \\
\hline Parasitism (\%) & $85 \pm 6.30$ & $98 \pm 1.00$ & 380 & 0.14124 \\
\hline Emergency (\%) & $83.5 \pm 6.2$ & $50.4 \pm 5.00$ & 148 & 0.00000616 \\
\hline Non-emerged parasitized eggs (\%) & $3.8 \pm 1.40$ & $48 \pm 5.00$ & 45 & 8.5745E-06 \\
\hline Egg-to-adult period (days) & $11.74 \pm 0.08$ & $9.9 \pm 0.38$ & 91 & 1.4143E-07 \\
\hline Sex ratio & $0.6 \pm 0.01$ & $0.7 \pm 0.05$ & 272.5 & 0.0347 \\
\hline Female longevity (days) & $2.74 \pm 0.08$ & $1.5 \pm 0.10$ & 82 & 3.119E-08 \\
\hline Male longevity (days) & $2.6 \pm 0.06$ & $1.9 \pm 0.19$ & 248 & 0.002142 \\
\hline
\end{tabular}

${ }^{1}$ Results based on 430 eggs. Values in bold are significantly different. 


\section{Discussion}

This study provides information about a Brazilian endemic species that is not found in the literature available on biological cycles, host plants and natural enemies. The occurrence of $G$. dubia in rice (Oryza sativa L.) is being recorded for the first time, opening perspectives for an update of Pentatomidae and egg parasitoid species and thus reinforcing rice integrated pest management in Brazil.

Glyphepomis contains seven species that are morphologically similar (Bianchi et al., 2016), and only a few studies have investigated them, including biology studies of G. spinosa in rice (Alves et al., 2012) and the occurrence of parasitism by Te. podisi on G. adroguensis (Farias et al., 2012).

No studies have been carried out to evaluate the biology of Te. podisi and Tr. basalis in eggs of any Glyphepomis species in Brazil. The literature reports several surveys of Te. podisi and Tr. basalis parasitizing eggs of other pentatomids in rice fields (Idalgo et al., 2013; Maciel et al., 2007; Zachrisson et al., 2014a, b).

In the cages, nymphs and adults were observed feeding on the stalks of rice with upside down position. This behavior was also verified for other rice stink bugs, T. limbativentris (Ferreira et al., 1997; Ferreira, 2006), G. spinosa (Alves et al., 2012), G. adroguensis (Farias et al., 2012) and also in corn with Diceraeus melacanthus (Dallas) (Panizzi and Lucini, 2019).

Throughout the experiment, rice plants proved to be important nutritional sources for the development of immatures and adults of. G. dubia, it can be inferred that the feed used was adequate in because it provided an expressive viability of the eggs obtained. Egg incubation time and viability are close to those observed for $G$. spinosa (Alves et al., 2012). Matesco et al. (2009) also found a high percentage of egg viability in Chinavia longicorialis (Breddin) fed green bean pods (Phaseolus vulgaris L.) under controlled conditions. The high egg viability observed in this study indicates that if the population of G. dubia increases in rice fields, significant yield losses can occur due to the high fertility of adults in the field.

The oviposition site is preferably the upper surface of the leaves or stems of rice that can facilitate both chemical or biological management carried out by natural enemies. The eggs of G. dubia are barrel-shaped, light green and similar in shape to those of G. spinosa (Pollo et al., 2012) and Cyptocephala alvarengai Rolston (Barrigossi et al., 2017) right at this stage of development in field conditions may make it difficult to identify G. dubia when other rice stink bugs occur in the crop.

The survival rates of nymphs are influenced by temperature according to Oliveira et al. (2019) in studies with Corythucha gossypii Fabricius (Hemiptera: Tingidae). The low survival of $C$. alvarengai nymphs in the second instar has also been reported by Barrigossi et al. (2017), with lower mortality in the subsequent instars; also, high mortality from the second to the fifth instar was observed in C. longicorialis (Matesco et al., 2009).

Several factors may be associated with the low survival of pentatomid nymphs, such as food source (Matesco et al., 2009), biological mortality from natural enemies, temperature (Alves et al., 2012) and relative humidity (Alves et al., 2012; Hirose et al., 2006). As there is no other data available on alternative food sources or any reports in other host plants, it might be difficult to point out whether the survival of $G$. dubia nymphs will be low.

As for the incidence of natural enemies, this factor was not observed in the study as the plants were protected by cages and the eggs were removed daily to avoid parasitism. It was therefore not possible to observe other factors that may have influenced nymph behavior. Thus, further research on temperature and relative humidity is needed to better explain the low survival of $G$. dubia nymphs.

Considering the egg-to-adult development and the pre-oviposition period, the duration of one generation was about 49.9 days, similar to those observed for $G$. spinosa (Alves et al., 2012) and close to those observed for T. limbativentris (Bolton et al., 1996), a chronic rice pest in South America (Martins et al., 2009). In the State of Maranhão, Brazil, the preference of farmers is for rice varieties with intermediate to long life cycles ( $>85$ to 110 days), suggesting that $G$. dubia can have up to two generations per growing season.

Telenomus podisi seems to be a promising natural regulator of $G$. dubia eggs in rice fields, as it can successfully parasitize and develop in all stages of G. dubia embryonic development. This parasitoid has been also reported by Farias et al. (2012) in Brazil, with G. adroguensis and T. limbativentris as hosts (Maciel et al., 2007; Riffel et al., 2010), and by Zachrisson et al. (2018) in Panama with E. nicaraguensis as a host in a rice field.

The eggs parasitized by Tr. basalis showed an emergency of only $50.4 \%$. The host on which the female parasitoid oviposits is an important variable to be studied, and this factor was observed in the present study as the emergency was affected.

Parasitoid larval development may be dependent on specific nutrients from the host egg that are essential for embryonic development (Nettles Júnior, 1990), since during the development of immature forms the host is the only nutritional source available (Zhou et al., 2014). These nutrients are tissue components and if they are not present in the host egg the development of the parasitoid embryo is discontinued (Vinson, 1997), and low emergence rates or death of larvae can occur (Gomes, 1997).

The presence of dead pupae inside the eggs, seen by the number of parasitized eggs that did not emerge during egg dissection, indicates the occurrence of parasitism of Tr. basalis on G. dubia, although it may be influenced by factors that limit parasitoid development.

If the host is appropriate for the development of the parasitoid, the mortality of young forms is low (Rodrigues et al., 2003). The nutritional quality is a hypothesis that could explain the pupal mortality of $\mathrm{Tr}$. basalis in G. dubia eggs, however further studies should be carried out for a better understanding of this effect, as according to Queiroz et al. (2018) there are only a few published studies available.

From egg to adult, Te. podisi and Trissolcus brochymenae (Ashmead) took 14 days at $13.2^{\circ} \mathrm{C}$ and 16 days at $14.1^{\circ} \mathrm{C}$ to complete their cycle in Piezodorus guildinii (Westwood) eggs (Cividanes et al., 1998). For Tr. basalis in Nezara viridula (L.) 
eggs the duration was 11.45 days at $26^{\circ} \mathrm{C}$ (Corrêa-Ferreira, 1993). Telenomus podisi took 10.1 days at $25^{\circ} \mathrm{C}$ to develop in T. limbativentris eggs (Riffel, 2007), a time close to that observed in our study examining G. dubia eggs under the same temperature conditions.

The sex ratio of Te. podisi was similar to that obtained by Riffel (2007), when T. limbativentris eggs were used as host. In biological control programs, sex ratio is an important attribute considering that the higher proportion of females obtained from the offspring is decisive for the establishment of the parasitoid during the crop season (Navarro, 1998).

In general, the longevity of a parasitoid species is directly associated with a high parasitism rate, host and food supply (Corrêa-Ferreira, 1993; Pacheco and Corrêa-Ferreira, 1998; Riffel, 2007). Prolonged longevity was observed in females of Te. podisi, what can be an advantage for the species in view of the greater efficiency in the host's eggs observed by parasitism and emergence occurring in this study. Riffel (2007) reported a longevity of 5.97 days for Te. podisi in T. limbativentris eggs, while Corrêa-Ferreira (1993) reported 3.0 and 4.7 days for females and males of $T r$. basalis, respectively, in $N$. viridula eggs.

The biological characteristics of $G$. dubia are similar to those observed in other species of stink bugs found in rice crops, including their feeding behavior and development time. This allows us to conclude that this species may potentially achieve a pest status and, therefore, the monitoring of rice planting areas is highly recommended. Furthermore, Te. podisi is a promising biological control agent for G. dubia management in Brazil due to its higher longevity and better reproductive parameters.

\section{Acknowledgements}

We thank Fundação de Amparo à Pesquisa e ao Desenvolvimento Científico e Tecnológico do Maranhão (FAPEMA) and Conselho Nacional de Desenvolvimento Científico e Tecnológico (CNPq) for the fellowship provided to the first author (Process $n^{\circ}$.01394/11) and for the financial support. We also thank Dr. L. A. de Campos (UFRGS, Brazil) for identifying the pentatomids.

\section{References}

ACOSTA, L.G., JAHNKE, S.M., REDAELLI, L.R. and PIRES, P.R.S., 2017. Insect diversity in organic rice fields under two management systems of levees vegetation. Brazilian Journal of Biology = Revista Brasileira de Biologia, vol. 77, no. 4, pp. 731-744. http://dx.doi. org/10.1590/1519-6984.19615. PMid:28355392.

ALVES, T.M., BARRIGOSSI, J.A.F. and QUINTELA, E.D., 2012. Life cycle of Glyphepomis spinosa Campos \& Grazia (Hemiptera: Pentatomidae): a new pest of rice in Brazil. Neotropical Entomology, vol. 41, no. 6, pp. 437-441. http://dx.doi.org/10.1007/ s13744-012-0067-3. PMid:23949667.

BARRIGOSSI, J.A.F., SILVA, C.V., ALONSO, J.D.S. and HIROSE, E., 2017. Notes on biology of the stink bug Cyptocephala alvarengai Rolston (Hemiptera: Pentatomidae) feeding on rice panicles. The Florida Entomologist, vol. 100, no. 4, pp. 823-825. http:// dx.doi.org/10.1653/024.100.0412.
BIANCHI, F.M., GONÇALVES, V.R., SOUZA, J.R. and CAMPOS, L.A., 2016. Description of three new species of Glyphepomis Berg (Heteroptera: Pentatomidae: Pentatominae).Zootaxa, vol. 4103, no. 5, pp. 443-452. http://dx.doi.org/10.11646/zootaxa.4103.5.2. PMid:27394747.

BOLTON, M., MARTINS, J.F.S., LOECK, A.E. and ROSENTHAL, M.Á., 1996. Biologia de Tibraca limbativentris Stål sobre plantas de arroz. Anais da Sociedade Entomológica do Brasil, vol. 25, no. 1, pp. 21-26. http://dx.doi.org/10.37486/0301-8059.v25i1.1085.

CIVIDANES, F.J., FIGUEIREDO, J.G. and CARVALHO, D.R., 1998. Previsão da emergência de Trissolcus brochymenae Ashmead e Telenomus podisi Ashmead (Hymenoptera: Scelionidae) em condições de campo. Scientia Agrícola, vol. 55, no. 1, pp. 43-47. http://dx.doi.org/10.1590/S0103-90161998000100008.

COMPANHIA NACIONAL DE ABASTECIMENTO - CONAB, 2021 [viewed 11 January 2021]. Acompanhamento de safra brasileira de grãos: sexto levantamento, safra 2020/2021. Brasília: CONAB. Boletim da Safra de Grãos, vol. 8, no. 6, 106 p. Available from: https://www.conab.gov.br/info-agro/safras/graos/boletimda-safra-de-graos

CORRÊA-FERREIRA, B.S., 1993. Utilização do parasitoide de ovos Trissolcus basalis (Wollaston) no controle de percevejos da soja. Londrina: Embrapa Soja, Circular Técnica, no. 11, 40 p.

DOETZER, A.K. and FOERSTER, L.A., 2007. Desenvolvimento, longevidade e reprodução de Trissolcus basalis (Wollaston) e Telenomus podisi Ashmead (Hymenoptera: Scelionidae) em condições naturais durante a entressafra da soja no Sul do Paraná. Neotropical Entomology, vol. 36, no. 2, pp. 233-242. http://dx.doi. org/10.1590/S1519-566X2007000200009. PMid:17607456.

FARIAS, P.M., KLEIN, J.T., SANT'ANA, J., REDAELLI, L.R. and GRAZIA, J., 2012. First records of Glyphepomis adroguensis (Hemiptera, Pentatomidea) and its parasitoid Telenomus podisi (Hymenoptera, Platygastridae), on irrigated rice fields in Rio Grande do Sul, Brazil. Revista Brasileira de Entomologia, vol. 56, no. 3, pp. 383-384. http://dx.doi.org/10.1590/S008556262012005000044 .

FERREIRA, E. 2006. Fauna prejudicial. In: A.B. SANTOS, L.F. STONE and N.R.A. VIEIRA, eds. A cultura do arroz no Brasil. Santo Antônio de Goiás: Embrapa, pp. 485-560.

FERREIRA, E., 1998. Manual de identificação de pragas do arroz. Santo Antônio de Goiás: Embrapa Arroz e Feijão, Documentos, no. 90, 110 p.

FERREIRA, E., ZIMMERMANN, F.J.P., SANTOS, A.B. and NEVES, B.P., 1997. 0 percevejo-do-colmo na cultura do arroz. Santo Antônio de Goiás: Embrapa Arroz e Feijão, 43 p. Documentos, no. 75.

GOMES, S.M., 1997. Comparação de três hospedeiros alternativos para criação e produção massal de Trichogramma pretiosum Riley, 1879 e T. galloi Zucchi, 1988. Piracicaba: Universidade de São Paulo, 106 p. Dissertação de Mestrado em Entomologia.

HAMMER, Ø., HARPER, D.A.T. and RYAN, P.D., 2001 [viewed 11 January 2021]. PAST: Pacote de Software de Estatística Paleontológica para Educação e Análise de Dados. Palaeontologia Electronica [online], vol. 4, no. 1, pp. 1-9. Available from: http http://palaeo-electronica.org/2001_1/past/issue1_01.htm

HIROSE, E., PANIZZI, A.R. and CATTELAN, A.J., 2006. Effect of relative humidity on emergence and on dispersal and regrouping of first instar Nezara viridula (L.) (Hemiptera: pentatomidae). Neotropical Entomology, vol. 35, no. 6, pp. 757-761. http://dx.doi. org/10.1590/S1519-566X2006000600006. PMid:17273705.

IDALGO, T.D.N., SANT'ANA, J., REDAELLI, L.R. and PIRES, P.D.S., 2013. Parasitismo de ovos de Tibraca limbativentris Stal (Hemiptera: Pentatomidae) em lavoura de arroz irrigado, Eldorado do Sul, 
RS. Arquivos do Instituto Biológico, vol. 80, no. 4, pp. 453-456. http://dx.doi.org/10.1590/S1808-16572013000400014.

MACIEL, A.A., DE LEMOS, R.N., DE SOUZA, J.R., COSTA, V.A., BARRIGOSSI, J.A. and DAS CHAGAS, E.F., 2007. Parasitismo de ovos de Tibraca limbativentris Stal (Hemiptera: Pentatomidae) na cultura do arroz no Maranhão. Neotropical Entomology, vol. 36, no. 4, pp. 616-618. http://dx.doi.org/10.1590/S1519566X2007000400023. PMid:17934631.

MARTINS, J.F.S., BARRIGOSSI, J.A.F., OLIVEIRA, J.V. and CUNHA, U.S., 2009. Situação do manejo integrado de insetos-praga na cultura do arroz no Brasil. Pelotas: Embrapa Clima Temperado, Documentos, no. 290, 40 p.

MARTINS, J.F.S., BOTTON, M., CARBONARI, J.J. and QUINTELA, E.D., 2004. Eficiência de Metarhizium anisopliae no controle do percevejo-do-colmo Tibraca limbativentris (Heteroptera: Pentatomidae) em lavoura de arroz irrigado. Ciência Rural, vol. 34, no. 6, pp. 1681-1688. http://dx.doi.org/10.1590/S010384782004000600003 .

MATESCO, V.C., SCHWERTNER, C.F. and GRAZIA, J., 2009. Morphology of the immatures and biology of Chinavia longicorialis (Breddin) (Hemiptera: pentatomidae). Neotropical Entomology, vol. 38, no. 1, pp. 820-828. http://dx.doi.org/10.1590/S1519566X2009000100007. PMid:19347099.

MELO NETO, A.J., DE SOUZA, J.R., SANTIAGO, C.M., PEREIRA, F.A.S., LIMA, M.H.F. and WENGRAT, A.P.G.S., 2020. Primeiro registro de parasitoides de ovos de Oebalus poecilus (Dallas, 1851) (Hemiptera: Pentatomidae) em arroz no Maranhão, Brasil. Entomological Communications, vol. 2, pp. ec02032. http:// dx.doi.org/10.37486/2675-1305.ec02032.

NAVARRO, M.A., 1998. Trichogramma spp. producción, uso y manejo en Colombia. Guadalajara de Buga: Impretec, 176 p.

NETTLES JUNIOR, W.C., 1990. In vitro rearing of parasitoids: role of host factors in nutrition. Archives of Insect Biochemistry and Physiology, vol. 13, no. 3, pp. 167-175. http://dx.doi.org/10.1002/ arch.940130304.

OLIVEIRA, S.R., SILVA, C.A.D., CARVALHO, T.S. and COSTA, L.A.A., 2019. Biology of Corythucha gossypii Fabricius, 1794 (Hemiptera: Tingidae) in Ricinus communis at different temperatures and thermal requirements. Brazilian Journal of Biology = Revista Brasileira de Biologia, vol. 79, no. 2, pp. 278-285. http://dx.doi. org/10.1590/1519-6984.180501. PMid:30088527.

PACHECO, D.J.P. and CORRÊA-FERREIRA, B.S., 1998. Potencial reprodutivo e longevidade do parasitoide Telenomus podisi Ashmead, em ovos de diferentes espécies de percevejos. Anais da Sociedade Entomológica do Brasil, vol. 27, no. 4, pp. 585-591. http://dx.doi.org/10.1590/S0301-80591998000400011.

PACHECO, D.J.P. and CORRÊA-FERREIRA, B.S., 2000. Parasitismo de Telenomus podisi Ashmead (Hymenoptera: Scelionidae) em populações de percevejos pragas da soja. Anais da Sociedade Entomológica do Brasil, vol.29, no. 2, pp. 295-302. http://dx.doi. org/10.1590/S0301-80592000000200011.

PANIZZI, A.R. and LUCINI, T., 2019. Body position of the stink bug Dichelops melacanthus (Dallas) during feeding from stems of maize seedlings. Brazilian Journal of Biology $=$ Revista Brasileira de Biologia, vol. 79, no. 2, pp. 304-310. http://dx.doi. org/10.1590/1519-6984.18250. PMid:30133556.

PASTORI, P.L., MONTEIRO, L.B., BOTTON, M. and PRATISSOLI, D., 2010. Efeito da idade do parasitoide e do hospedeiro na reprodução de Trichogramma pretiosum Riley (Hymenoptera: Trichogrammatidae) em ovos de Bonagota salubricola (Meyrick) (Lepidoptera: Tortricidae). Arquivos do Instituto Biológico, vol. 77, no. 2, pp. 349-353. http://dx.doi.org/10.1590/18081657v77p3492010.
PAZINI, J.B., BOTTA, R.A., SEIDE, J.E., SILVA, F.F., MARTINS, J.F.S., BARRIGOSSI, J.A.F. and RÜBENICH, R., 2015. Geoestatística aplicada ao estudo da distribuição espacial de Tibraca limbativentris em arrozal irrigado por inundação. Ciência Rural, vol. 45, no. 6, pp. 1006-1012. http://dx.doi.org/10.1590/01038478 cr20140841.

POLLO, P., GREVE, C., MATESCO, V.C. and GRAZIA, J., 2012. Description of the immature stages of Glyphepomis spinosa Campos \& Grazia (Hemiptera: Pentatomidae: Pentatominae: Carpocorini). Zootaxa, vol. 3566, no. 1, pp. 61-68.

QUEIROZ, A.P., TAGUTI, E.A., BUENO, A.F., GRANDE, M.L.M. and COSTA, C.O., 2018. Host preferences of Telenomus podisi (Hymenoptera: Scelionidae): Parasitism on eggs of Dichelops melacanthus, Euschistus heros and Podisus nigrispinus (Hemiptera: Pentatomidae). Neotropical Entomology, vol. 47, no. 4, pp. 543-552. http://dx.doi.org/10.1007/s13744-017-0564-5. PMid:29159796.

RAHAMAN, M.M. and STOUT, M.J., 2019. Comparative efficacies of next-generation insecticides against yellow stem borer and their effects on natural enemies in rice ecosystem. Rice Science, vol. 26, no. 3, pp. 157-166. http://dx.doi.org/10.1016/j. rsci.2019.04.002.

RIFFEL, C.T., 2007. Levantamento e aspectos biológicos de espécies parasitoides de posturas do percevejo-do-colmo-do-arroz no estado de Santa Catarina. Lages: Centro de Ciências Agroveterinárias, 73 p. Dissertação de Mestrado em Produção Vegetal.

RIFFEL, C.T., PRANDO, H.F. and BOFF, M.I.C., 2010. Primeiro relato de ocorrência de Telenomus podisi (Ashmead) e Trissolcus urichi (Crawford) (Hymenoptera: Scelionidae) como parasitóides de ovos do percevejo-do-colmo-do-arroz, Tibraca limbativentris (Stål) (Hemiptera: Pentatomidae), em Santa Catarina. Neotropical Entomology, vol. 39, no. 3, pp.447-448. http://dx.doi.org/10.1590/ S1519-566X2010000300021. PMid:20676521.

RODRIGUES, S.M.M., BUENO, V.H.P. and SAMPAIO, M.V., 2003. Tabela de vida de fertilidade de Lysiphlebus testaceipes (Cresson. 1880) (Hymenoptera, Aphidiidae) em Schizaphis graminum (Rondani, 1852)(Hemiptera. Aphidiidae). Revista Brasileira de Entomologia, vol. 47, no. 4, pp. 637-642. http://dx.doi.org/10.1590/S008556262003000400017.

VINSON, S.B., 1997. Comportamento de seleção hospedeira de parasitoides de ovos, com ênfase na família Trichogrammatidae. In: J.R.P. PARRA and R.A. ZUCCHI, eds. Trichogramma e o controle biológico aplicado. Piracicaba: FEALQ, pp. 67-119.

ZACHRISSON, B., GRAZIA, J., POLANCO, P. and OSORIO, P.O., 2018. New reports of host plants of Euchistus nicaraguensis Rolston, 1972 (Heteroptera: Pentatomidae) and natural parasitism of Telenomus podisi Ashmead, 1893 (Hymenoptera: Platygastridae) in the rice agricultural ecosystem in Panama. Brazilian Journal of Biology = Revista Brasileira de Biologia, vol. 78, no. 3, pp. 593-594. http://dx.doi.org/10.1590/1519-6984.170740. PMid:29160364.

ZACHRISSON, B., MARGARÍA, C.B., LOIÁCONO, M. and MARTÍNEZ, O., 2014a. Parasitismo de huevos de Tibraca limbativentris (Hemiptera: Pentatomidae) en arroz (Oryza sativa) en Panamá. Revista Colombiana de Entomologia, vol. 40, no. 2, pp. 185-186.

ZACHRISSON, B., VALMIR, C. and BERNAL, J., 2014b. Incidência natural de parasitoides de huevos de Oebalus insularis Stal (Heteroptera: Pentatomidae) en Panamá. Idesia, vol. 32, no. 2, pp. 119-121. http://dx.doi.org/10.4067/S0718-34292014000200016.

ZHOU, Y., ABRAM, P.K., BOIVIN, G. and BRODEUR, J., 2014. Increasing host age does not have the expected negative effects on the fitness parameters of an egg parasitoid. Entomologia Experimentalis et Applicata, vol. 151, no. 2, pp. 106-111. http:// dx.doi.org/10.1111/eea.12173. 